\title{
EFFECTS OF INITIAL SOIL CARBON AND METAL CONTENTS ON SORPTION OF DISSOLVED ORGANIC CARBON ON THE SOILS OF TROPICAL RAIN FOREST TRANSFORMATION SYSTEMS
}

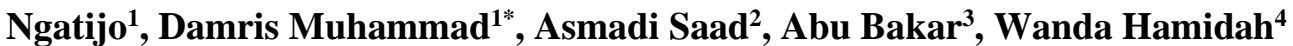 \\ ${ }^{1}$ Department of Chemistry, Faculty of Science and Technology, Jambi University \\ ${ }^{2}$ Department of Agro-technology, Faculty of Agriculture, Jambi University \\ ${ }^{3}$ Department of Chemistry Education, Faculty of Education, Jambi University \\ ${ }^{4}$ Department of Biology Author Education, Faculty of Education, Jambi University
}

\author{
damris@unja.ac.id
}

Artikel Info
Diterima
tanggal
14.01 .2021
Disetujui
publikasi
tanggal
30.04.2021
Kata kunci :
Dissolved
Organic
Carbon, Heavy
Metals, Total
Carbon
Contents, Soil,
Sorption

\begin{abstract}
ABSTRAK
Karbon organik terlarut (DOC) dalam tanah memainkan peran penting dalam distribusi nutrisi dan konsentrasinya dapat dipengaruhi oleh keberadaan partikel mineral tanah. Kandungan karbon tanah awal dapat mengurangi kapasitas tanah untuk menyerap DOC karena adanya tolakan muatan negatif. Penelitian ini mengkaji pengaruh kandungan karbon dan logam tanah awal terhadapa dsorpsi DOC yang ditambahkan pada tanah hutan tropis melalui percobaan batch. Kandungan logam berat tanah ( $\mathrm{Al}$ dan $\mathrm{Fe})$, total karbon organik dan kandungan DOC tanah ditentukan. Untuk menentukan apakah dan bagaimana variasi kandungan karbon tanah mempengaruhi adsorpsi DOC, maka dua tanah dengan kandungan logam dan karbon yang berbeda (tanah permukaan dan bawah permukaan) dari dua sistem transformasi (hutan tropis sekunder dataran rendah dan perkebunan sawit masyarakat digunakan. Karbon organik terlarut diekstraksi dari permukaan tanah yang kaya organik dengan air dan dipekatkan ketingkat yang diperlukan dan digunakan dalam percobaan batch. Karbon organik terlarut berkorelasi negatif dengan kandungan logam tanah terutama pada sub permukaan tanah. Dengan kandungan organik karbon tinggi korelasinya tidak signifikan. Ini mungkin menjelaskan adanya tolakan DOC yang membawa perubahan negatif oleh partikel tanah kaya organik.
\end{abstract}

\section{ABSTRACT}

Dissolved organic carbon (DOC) in soil plays a significant role water could be affected significantly due to absorption on soil mineral particles but initial soil carbon contentmight reduce the capacity of soil to absorbDOC due to repulsive negative bearing charges. This study investigated the effect of initial soil carbon and metal contents on adsorption of added DOC on the soil of tropical forest through batch experiments. Soil heavy metals ( $\mathrm{Al}$ and $\mathrm{Fe}$ ), total organic carbon and DOC contents in the soils were measured. In order to determine whether and to what extant variation in metal and carbon contents of the soil affect the DOC adsorption, two soils with different metal and carbon contents (top and sub surface soils) from two transformation systems (secondary lowland tropical forest and small holder palm oil plantation) were used. Dissolved organic carbon was extracted from organic-rich surface soil with water and concentrated to a required levels and used in batch experiments. Dissolved organic carbon correlates negatively with soil metal contents particularly at soil sub surface. In presence of high carbon organic contents the correlation is not significant. This may explainrepulsion of DOC bearing negative changes by organic rich soil particles

http://dx.doi.org/10.23960/aec.v6.i1.2021.p12-21

Anal.Environ.Chem. 


\section{INTRODUCTION}

Transformation of tropical rainforest is still undergoing and mainly driven by expansion of oil palm, rubber, mining and timber (Abood et al., 2014; Laumonier et al., 2010). Area of oil palm plantation has significantly increased in the last decade and reached 17 million hectares world wide. Indonesia contributed for $60 \%$ of this increase and is now the main producer of palm oil (FAO, 2014). It has been widely recognized that transformation of tropical forest to intensive agricultural plantation mightresult in modification of soils properties and processes (McGrath et al., 2001; Ross, 1993) and thus affects soil organic carbon and dissolved organic carbon in soil water (Don et al., 2011; Van Noordwijk et al., 1997).

Dissolved organic carbon in soil water plays an important role in both carbon cycling and chemistry of soils, through its influence on acidity, nutrient availability, metal toxicity and transport. It is the most dynamic and mobile fraction of the soil carbon and interacts with soil solid through adsorption-desorption mechanisms or to be taken by soil biota and plant roots, along with heavy metals. Dissolved organic carbon could stay dissolved in the soil solution and involve in dissolution equilibria of metals in the soil solution and reduce metal adsorption. In this case, soil surfaces compete more effectively for the free metal ion with forming soluble organometallic complexes or being preferentially adsorbed onto the surfaces instead of the metals it is competing with. Types and amounts of minerals present in the soils are of considerable importance in determining whether DOC stays in the solution in the form of organo-metal complexes or be weakly adsorbed to the soil surface, or form strong inner-sphere complexes that are bound even more strongly than would the free metal ion.

Although many adsorptionstudies have confirmed of such possible of DOC- metals interaction in soil solution, a lack of information concerning the influenceof initial carbon and heavy metal contents of the soils onthe added-DOC adsorption needs morestudy. We investigated the effect of in situ initial organic carbon and heavy metal contents in the soils on adsorption of DOC added to the soils in lab experiments. We used soils collected from tropical rainforest and the transformed oil palm plantation in Jambi. We hypothesized that adsorption of DOC on the soils decreases with total carbon content but increase with heavy metal in the soils. Nevertheless, the DOC sorption would be mainly pronounced in mineral soils rather than organic-rich soils. We assume that the $\mathrm{C}$ content and the soil composition in the subsoil under 
the plantations were similar to the $\mathrm{C}$ content and the soil compositionin the subsoil of the forest before the conversion.

\section{METHOD}

\section{Materials and Reagents}

Plastic spoon was used to collect soil samples, plastic bag and boxes holder for transportation of soil samples, 2-mm sieve, freezer for sample storage in the lab, mortar and pestle for soil graining, centrifuge for separation water-extractable organic carbon, analytical balance, hot plate, magnetic stirrer, $0.45-\mu \mathrm{m}$ glass membrane filter, UV-VIS spectrophotometer, LECO CHN-1000 and Atomic Absorbtion Spectrophotometer (AAS). Chemicals used in this study were $\mathrm{KMnO}_{4}$, deionize water, $\mathrm{FeCl}_{2}, \mathrm{AlCl}_{3}, \mathrm{H}_{2} \mathrm{SO}_{4}$.

\section{Preparation of soil samples}

Soil samples were collected from a small holder of palm oil plantations in Muaro Jambi, Jambi Province. The top organic soil $(10 \mathrm{~cm})$ and sub soils $(30-50 \mathrm{~cm})$ were collected from a number of randomly selected points ( 3 points) across the site and placed into clean plastic bags and sealed. Upon return to the laboratory, the soil was sieved through a2-mm mesh and then stored in freezer at $-5^{\circ} \mathrm{C}$. Soils collected from secondary forest proximate from the palm oil plantationwere also treated as above.

\section{Total C content}

Total $\mathrm{C}$ content in the soils was determined by dry combustion. Approximately $200 \mathrm{mg}$ of the grained soil samples was covered in tinfoil before the analysis. The samples were combusted and the $\mathrm{C}$ was oxidized to $\mathrm{CO}_{2}$ which was measured by infrared light (LecoCHN-1000). The data was reported on dry basis.

\section{Extraction of soil DOC}

Dissolved organic carbon was prepared by aqueous extraction of organic rich soil from secondary forest near the small holder palm oil plantation in Muaro Jambi. The extraction was performed by adding $200 \mathrm{~g}$ soils to 1 liter of deionized water. The suspension was stirred for 24 
$\mathrm{h}$ at $180 \mathrm{rpm}$. The suspensions were centrifuged at $14.000 \mathrm{rpm}$ for 10 minat $25^{\circ} \mathrm{C}$. The supernatants were filtered over a $0.45-\mu \mathrm{m}$ glass fibremembrane filter. Five soil extracts were combined together and concentrated to obtain $150 \mathrm{mg} \mathrm{CL}^{-1}$ as stock solution. The resulted DOC solution wasstored in freezer at $-5{ }^{\circ} \mathrm{C}$ until used for other experiments within 2 weeks. Otherwise, new DOC solution was made.

\section{Analysis of DOC}

Dissolved organic carbon was analyzed with indirect method of $\mathrm{KMnO}_{4}$ as oxidizing agent. The solutions of DOC were added with an excess of $\mathrm{KMnO}_{4}$ and left over for 10 min to ensure complete DOC oxidation. Absorbances of unreacted $\mathrm{KMnO}_{4}$ solution were determined with UV-VIS Spectrophotometer at $\lambda_{\max } 565 \mathrm{~nm}$. The absorbance difference between before and after the reaction was used to estimate DOC concentrations in the solution.

\section{Analysis of soil metal contents}

Total $\mathrm{Fe}$ and $\mathrm{Al}$ contents in the soils were determined on grinded and oven-dried soil using destructive method of AAS. Accurately weighted solids ( 2 gr) were added to $100-\mathrm{ml}$ beaker glass containing $10-\mathrm{ml}$ concentrated $\mathrm{H}_{2} \mathrm{SO}_{4}$ covered by watch-glass on a hot plat. The suspension was slowly heated up to $230^{\circ} \mathrm{C}$ while dropwise $\mathrm{HNO}_{3}$ was added repeatedly until clear solution was obtained. The suspension was filtered off Whatman-41 paper to a 50-ml measuring glass and diluted with distillated water to the mark. The Fe and Al contents were determined by AAS.

\section{Equilibria experiments}

The DOC adsorption experiments conducted on duplicates of 0, 20, 40, 80 dan $150 \mathrm{mg} \mathrm{C}$ $\mathrm{L}^{-1}$ were prepared by diluting the stock DOC solution $\left(150 \mathrm{mg} \mathrm{CL}^{-1}\right)$. The initial DOC solution $(30 \mathrm{~mL})$ and $3 \mathrm{~g}$ of soil were added to a $100 \mathrm{~mL}$ glass bottleon a magnetic stirrer and agitated for 24 hours $\left(100\right.$ cycles/min), at $4{ }^{\circ} \mathrm{C}$. The final solution was filtrated off a $0.45 \mu \mathrm{m}$ glass fibre membrane filter and analysed for DOC. Six standards of $\mathrm{KMnO}_{4}$ were used $\left(0,1 \times 10^{-4}, 2 \times 10^{-4}\right.$, $3 \times 10^{-4}, 4 \times 10^{-4}, 5 \times 10^{-4}$ and $\left.6 \times 10^{-4} \mathrm{M}\right)$ to construct a standard curve. The amount DOC adsorbed was estimated by taking the difference between the concentration before and after adsorption 
equilibrium by assuming that each 1 mole $\mathrm{KMnO}_{4}$ reacted with 0.75 mole carbon. The procedure was repeated for all other solutions.

\section{RESULTS AND DISCUSSION}

\section{Calibration curve of $\mathrm{KMnO}_{4}$}

The calibration curve for determination of $\mathrm{KMnO}_{4}$ absorption were determined by measuring absorbance of the five standard solutions $\left(0,2 \times 10^{-4}, 4 \times 10^{-4}\right.$ and $\left.6 \times 10^{-4} \mathrm{~mole}^{-1}\right)$ at max wavelength (Figure 1). The result shows that Figure 1. It shows that good sensitivity and linearity of the UV-VIS instrument used to measure absorbances of KMnO4. The straight line equation of $\mathrm{A}=0,163\left[\mathrm{KMnO}_{4}\right]+0,0034$ and $\mathrm{r}^{2} 0,997$.

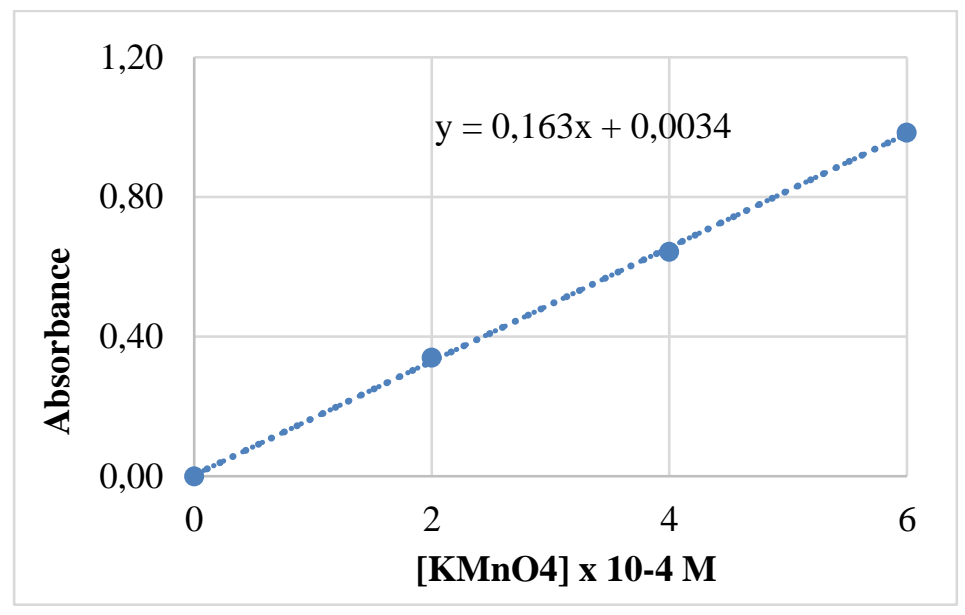

Figure 1. Calibration curve of $\mathrm{KMnO}_{4}$

\section{Characteristics of the soils}

The data given in table 1 shows total Fe, total $\mathrm{Al}$, total $\mathrm{C}$ and DOC in top and bottom soils of small holder palm oil plantation and secondary forest. the soils correlated with Al total in the small holder palm oil significantly, but in the secondary forest soil. Total Fe in both soils is higher than Al. Carbon total of top soils palm oil plantation and secondary forest is not significantly different $(\mathrm{P}<0.05)$.

Sample A showed in general a low content of both Al and Fe sesquioxides (Table 2); however, the variation between field replicates was high. The contrasting soil B had a high Fe 
content, while the $\mathrm{Al}$ content was not higher than for $\mathrm{A}$. In comparison, sample $\mathrm{C}$ had a larger $\mathrm{Al}$ content and a muchlower Fe content. Sample $\mathrm{C}$ was rich in amorphous Al, approximately five times higher than the average. Sample B showed a higher content of amorphous and crystalline Fe than the two other soils. Sample Ahad in general low clay content; most field replicates had a clay fraction lower than $10 \%$, and asfor other properties, the variability was high. The soil $\mathrm{C}$ content was $1.7 \pm 0.8 \%$ for $\mathrm{P} 1,1.3 \%$ for $\mathrm{P} 3$, and $2.3 \%$ for $\mathrm{B}$. There was not seen any great differences in $\mathrm{pH}$ between the three soils. The calculated hydrophobicity index (HI) for the Bhorizons ranged between 9.5 and 12 and from 2.3to 3.8 for the O-horizon samples.

$\mathrm{P}$ significantly; and the available K pool of PMF in the primary succession stage was lower as compared to MEBF forest typein the climax succession stage. This was consistent with the results of a study of a tropical wet forest soil in Costa Rica (Gunina, et al., 2014). Plant cover type and its considerable influence on soil properties has been reported in earlier studies (Islam, et al., 2000; Garten, at al., 2006), with lowland tropical forests having less P returned to the soilthrough litterfall. In stable environments, however, soil nutrientloss is gradual under relatively humid conditions as reported in Hawaiian ecosystems. Differences between soil quality indexes is mainly caused by various biotic and abiotic conditions such as forest soil litter, microbial biomass and their associated activities, and the initial soil properties. In tropicalforest ecosystems, soil property is very complex due to havinga closer relationship with succession. Our results for this lower subtropical forest are consistent with studies reporting complicated changes of soil properties with forest succession, but long term monitoring should be implemented for a more complete understanding. The pattern for available $\mathrm{Zn}, \mathrm{Cu}$, Feand $\mathrm{B}$ shows an increasing tendency in forest succession which is explained by the increase in organic matter that provides more exchangeable sites for cations, or the influenceof the $\mathrm{pH}$ value, because $\mathrm{H}$ ions are released by the decomposition of organic matter and by direct root exudation. All four elements favour leaching of nutrient cations because of competition for the exchange sites. The pattern of the fourelements was consistent with our hypothesis. 
Table 1. Concentrations of $\mathrm{Fe}(\%), \mathrm{Al}(\%), \mathrm{C}$ total (\%) and $\mathrm{DOC}\left(\mathrm{ug} \mathrm{g}^{-1}\right)$ in the top soil (0-10 $\mathrm{cm})$ and bottom soil $(30-50 \mathrm{~cm})$ of small holder palm oil plantation and secondary forest, Muaro Jambi $(\mathrm{n}=3)$

\begin{tabular}{ccccc}
\hline \multirow{2}{*}{ Soil of Palm Oil Plantation } & \multicolumn{4}{c}{ Mean \pm SD } \\
\cline { 2 - 5 } & $\mathrm{Fe}(\%)$ & $\mathrm{Al}(\%)$ & $\mathrm{C}$ Total $(\%)$ & $\mathrm{DOC}\left(\mathrm{ug} \mathrm{g}^{-1}\right)$ \\
\hline - Top 10 cm & $0,26 \pm 0,05$ & $0,18 \pm 0,11$ & $4,17 \pm 0,50$ & $13.25 \pm 2,00$ \\
• Bottom 30-50 cm & $2,67 \pm 0,46$ & $2,30 \pm 0,92$ & $1,73 \pm 0,46$ & $5,93 \pm 1,53$ \\
Soils of Secondary Forest & & & & \\
- Top 10 cm & $2,03 \pm 0,40$ & $1,30 \pm 0,17$ & $7,25 \pm 0,46$ & $26,75 \pm 3,03$ \\
- Bottom 30-50 cm & $2,83 \pm 0,55$ & $1,76 \pm 0,50$ & $1,92 \pm 0,31$ & $10,05 \pm 2,00$ \\
\hline
\end{tabular}

Table 2. Correlation coefficients between $\mathrm{Fe}, \mathrm{Al}, \mathrm{C}$ total and DOC at top and bottom of the soil samples collected from small holders of the palm oil plantation (top) and secondary forest (bottom) in Muara Jambi, Jambi Province.

\begin{tabular}{|c|c|c|c|c|c|c|c|c|}
\hline $\begin{array}{l}\text { Palm oil } \\
\text { Plantation }\end{array}$ & Fe top & $\mathrm{Al}$ top & $\begin{array}{l}\text { C total } \\
\text { Top }\end{array}$ & DOC top & $\begin{array}{l}\mathrm{Fe} \\
\text { Bottom }\end{array}$ & $\begin{array}{l}\mathrm{Al} \\
\text { Bottom }\end{array}$ & $\begin{array}{l}\text { C total } \\
\text { Bottom }\end{array}$ & $\begin{array}{l}\text { DOC } \\
\text { Bottom }\end{array}$ \\
\hline \multicolumn{9}{|l|}{ Fe Top } \\
\hline Al Top & $0,941 * *$ & & & & & & & \\
\hline C totol Top & $-0,994 * *$ & $-0,898 * *$ & & & & & & \\
\hline DOC top & $-0,682 * *$ & $-0,888 * *$ & $0,596 * *$ & & & & & \\
\hline Fe Bottom & $0,932 * *$ & $0,756^{* *}$ & $-0,967 * *$ & $-0,371$ & & & & \\
\hline Al Bottom & 0,225 & $0,539 * *$ & $-0,115$ & $-0,866 * *$ & $-0,143$ & & & \\
\hline C total Bottom & 0,106 & $-0,235$ & $-0,217$ & $0,655^{* *}$ & 0,459 & $-0,945 * *$ & & \\
\hline DOC Bottom & $-0,412$ & $-0,694 * *$ & 0,307 & 0,307 & $-0,054$ & $-0,981 * *$ & $0,862 * *$ & \\
\hline
\end{tabular}

** Significant at 0,05 level

\begin{tabular}{lrrrrrrrr}
\hline $\begin{array}{l}\text { Secondary } \\
\text { Forest }\end{array}$ & \multicolumn{1}{rl}{ Fe top } & Al Top & $\begin{array}{l}\text { C total } \\
\text { Top }\end{array}$ & $\begin{array}{l}\text { DOC } \\
\text { Top }\end{array}$ & $\begin{array}{l}\text { Fe } \\
\text { Bottom }\end{array}$ & $\begin{array}{l}\text { Al } \\
\text { Bottom }\end{array}$ & $\begin{array}{l}\text { C total } \\
\text { Bottom }\end{array}$ & $\begin{array}{l}\text { DOC } \\
\text { Bottom }\end{array}$ \\
\hline Fe Top & & & & & & & & \\
Al Top & 0,140 & & & & & & & \\
C total Top & $-0,756^{* *}$ & $0,756^{* *}$ & & & & & & \\
DOC top & $-0,189$ & $-0,945^{* *}$ & $-0,500^{* *}$ & & & & & \\
Fe Bottom & $0,891^{* *}$ & $-0,577^{* *}$ & $-0,971^{* *}$ & 0,277 & & & \\
Al Bottom & $-0,999^{* *}$ & 0,115 & $0,737^{* *}$ & 0,219 & $-0,878^{* *}$ & & \\
C total Bottom & 0,459 & $-0,945^{* *}$ & $-0,929^{* *}$ & $0,786^{* *}$ & $0,812^{* *}$ & $-0,434$ & \\
DOC Bottom & $-0,371$ & $-0,866^{* *}$ & $-0,327$ & $0,982^{* *}$ & 0,091 & 0,397 & $0,655^{* *}$ & \\
\hline
\end{tabular}

** Significant at 0,05 level 
Table 1 shows the concentration of $\mathrm{Fe}$ and $\mathrm{Al}, \mathrm{C}$ total and DOC in soils of the small holder palm oil plantation and secondary forest of Muaro Jambi. Iron and Al are two heavy metals that are found in significant amount compared to other heavy metals. Both metals could be found in the amorphous forms of oxides, oxyhydroxides and hydroxides. The important of these elements in the soils due to high adsorption capacities and specific surface area (Yukselen and Kaya, 2008). While in the forms of inorganic crystalline forms are gibbsite $\left(\mathrm{Al}(\mathrm{OH})_{3}\right)$, heamatite $\left(\mathrm{Fe}_{2} \mathrm{O}_{3}\right)$ and goethite $(\mathrm{FeOOH})$. Gibbsite is the most common $\mathrm{Al}$ found insoils, which is usually formed by silica removal from kaolinite.
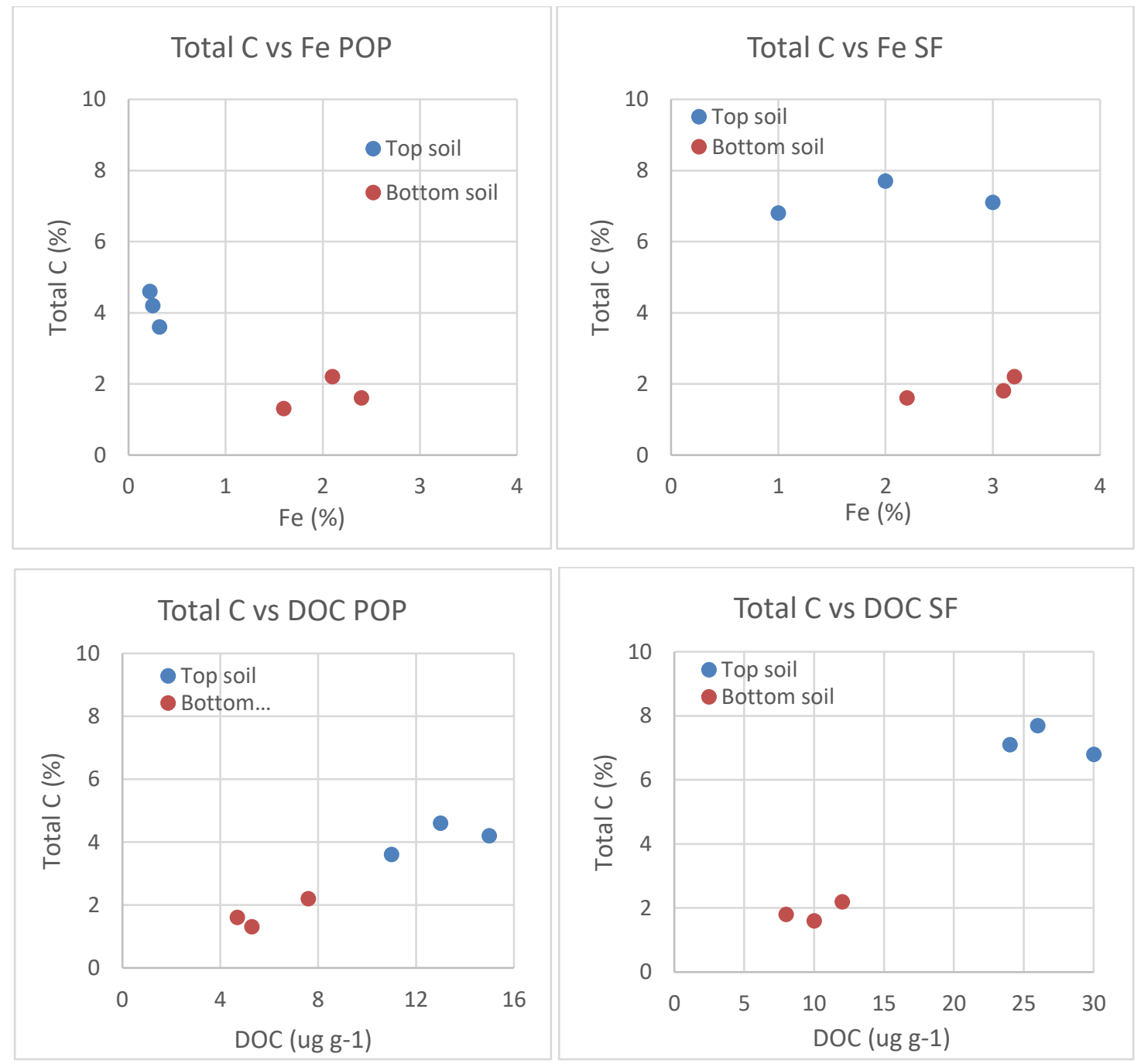

Figure 2. Contrasting behavior among soil parameters at top and bottom soils between $\mathrm{C}$ total and $\mathrm{Fe}$ (top) and $\mathrm{C}$ total and DOC between palm oil plantation (POP) and secondary forest (SF). 
Table 2 shows correlation coefficients among Fe, Al, C total, DOC at top and bottom of the soil samples collected at small holders palm oil plantation and secondary forest in Muaro Jambi Jambi Province.

Soil of palm oil plantation show a strong correlation between $\mathrm{Fe}$ and $\mathrm{Al}$ at top soil but not at the bottom soil. Fe and $\mathrm{C}$ total show a strong negative correlation at top soil but not at the bottom one. $\mathrm{C}$ total has a strong correlation with the DOC at both top and bottom soils. However, secondary forest shows that $\mathrm{Fe}$ and $\mathrm{Al}$ has no significant correlation at top and bottom soils. $\mathrm{C}$ total at top soil show a strong negative correlation with $\mathrm{Fe}$ and a strong positive correlation with Al. Figure 2 show a contrasting behavior among soil parameters at top and bottom soils between palm oil plantation (POP) and secondary forest (SF).

\section{CONCLUSIONS}

1. Conversion of lowland tropical rainforest to tree plantations decreases SOC stocks in the top soil. Extensive land use such as jungle rubber leads to lower decrease of SOC than intensive land uses such as oil palm and rubber plantations.

2. The vertical distributions of $\mathrm{C}$ contentfollow a power function with soil depth and a linear function with the log-transformed $\mathrm{C}$ content in Harapan and, to a lesser extend, in Bungku landscape.

3. Oil pam and intensive rubber plantations have similar impacts on SOC losses and erosion. However, the $\mathrm{C}$ enrichment of SOC suggests that the leaf litter is the main source of $\mathrm{C}$ for microorganisms in rubber plantations.

\section{ACKNOWLEDGEMENTS}

This study was supported financially by the Directorate General of Higher Education (DIKTI), Department of Research and Higher Education, Republic of Indonesia through the research scheme of International Research Collaboration and Publication (KLN). We also thank Prof. Yakov Kuzyakov of Gottingen University, Germany for this research collaboration and facilities provided during my visit to the Gottingen University.

$\overline{\text { http://dx.doi.org/10.23960/aec.v6.i1.2021.p12-21 }}$

Anal.Environ.Chem. 


\section{REFERENCES}

Abood, S.A., Lee, J.S.H., Burivalova, Z., Garcia-Ulloa, J., Koh, L.P., 2014, Relative contributions of the logging, fiber, oil palm, and mining industries to forest loss in Indonesia, Conserv. Lett., n/a-n/a. doi:10.1111/conl.12103.

Don, A., Schumacher, J., Freibauer, A., 2011, Impact of tropical land-use change on soil organic carbon stocks - a meta-analysis: Soil Organic Carbon And Land-Use Change, Glob. Change Biol., 17, 1658-1670. doi:10.1111/j.1365-2486.2010.02336.x.

FAO., 2014, FAOSTAT online statistical service, Food and Agriculture Organization of the United Nations (FAO), Rome, Italy. Available via URL. http://faostat.fao.org/, Accessed July 2014.

Garten Jr., C.T., 2006, Relationships among forest soil C isotopic composition, partitioning, and turnover times, Can. J. For. Res., 36, 2157-2167. doi:10.1139/x06-115.

Gunina, A., Kuzyakov, Y., 2014, Pathways of litter C by formation of aggregates and SOM density fractions: Implications from 13C natural abundance, Soil Biol. Biochem., 71, 95104. doi:10.1016/j.soilbio.2014.01.011.

Islam, K.R., Weil, R.R., 2000, Land use effects on soil quality in a tropical forest ecosystem of Bangladesh, Agric. Ecosyst. Environ., 79, 9-16.

Laumonier, Y., Uryu, Y., Stüwe, M., Budiman, A., Setiabudi, B., Hadian, O., 2010, Eco-floristic sectors and deforestation threats in Sumatra: identifying new conservation area network priorities for ecosystem-based land use planning, Biodivers. Conserv., 19, 1153-1174. doi:10.1007/s10531-010-9784-2.

McGrath, D.A., Smith, C.K., Gholz, H.L., Oliveira, F. de A., 2001, Effects of Land-Use Change on Soil Nutrient Dynamics in Amaz\&amp;\#x000F4;nia, Ecosystems., 4, 625-645. doi:10.1007/s10021-001-0033-0.

Ross, S.M., 1993, Organic matter in tropical soils: current conditions, concerns and prospects for conservation, Prog. Phys. Geogr., 17, 265-305. doi:10.1177/030913339301700301.

Van Noordwijk, M., Cerri, C., Woomer, P.L., Nugroho, K., Bernoux, M., 1997, Soil carbon dynamics in the humid tropical forest zone, Geoderma., 79, 187-225.

Yukselen Y and Kaya A., 2008, Suitability of the methylene blue test for surface area, cation exchange capacity andswell potential determination of clayey soils, Engineering Geology., 102. 38-45. 